\title{
Analisis Pengaruh Kecelakaan Kerja terhadap Produktivitas Kerja di CV. Karya Nugraha
}

\author{
Isma Masrofah $^{1 *}$, Muhamad Michael ${ }^{2}$ \\ ${ }^{1,2}$ Teknik Industri Universitas Suryakancana) \\ Jalan Pasir Gede raya Cianjur 43216 \\ 1*isma.masrofah@unsur.ac.id, ${ }^{2}$ muhamadmichael7777@gmail.com
}

\section{Analysis of Work Accidents Effect on Work Productivity at CV. Influence Analysis Works}

Dikirimkan: 09, 2020. Diterima: 09, 2020. Dipublikasikan: 09, 2020.

\begin{abstract}
CV. Karya Nugraha is a company engaged in manufacturing which produces medical devices or medical devices. CV. Karya Nugraha was founded in 2004. CV. Karya Nugraha does not escape the problems faced, such as disorganized storage of goods before processing which hinders the production process which can lead to work accidents. So that companies need control planning in the case of work accidents. This study aims to determine whether the level of work accidents affects the productivity level of employees at CV. Karya Nugraha. Based on the results of the study, the frequency of work accidents in 2016-2017 did not increase or decrease but productivity increased from 0.9902 to 0.9921 , This is influenced by the level of the number of hours worked which increases every year and is influenced by the number of hours of work lost that are less in 2017, which means a smaller accident severity.

Keywords - Work Accidents, Occupational Accident Frequency, Severity, Productivity
\end{abstract}

\begin{abstract}
Abstrak- CV. Karya Nugraha merupakan perusahaan yang bergerak di bidang manufaktur yang memproduksi alat-alat kesehatan atau alat-alat medis. CV. Karya Nugraha berdiri pada tahun 2004. CV. Karya Nugraha tidak luput dari masalah yang dihadapi seperti tidak teraturnya tempat penyimpanan barang sebelum diolah yang sangat menghambat dalam proses produksi yang dapat mengakibatkan kecelakaan kerja. Sehingga perusahaan perlu perencanaan pengendalian dalam kasus kecelakaan kerja. Penelitian ini bertujuan untuk mengetahui apakah tingkat kecelakaan kerja berpengaruh pada tingkat produktivitas karyawan di CV. Karya Nugraha. Berdasarkan hasil penelitian, tingkat frekuensi kecelakaan kerja pada tahun 2016-2017 kecelakaan tidak mengalami kenaikan maupun penurunan tetapi produktivitas mengalami peningkatan dari 0,9902 ke 0,9921, hal ini di pengaruhi oleh tingkat jumlah jam kerja yang meningkat setiap tahunnya dan dipengaruhi oleh jumlah jam kerja hilang yang lebih sedikit di tahun 2017, yang berarti tingkat keparahan kecelakaan yang lebih kecil.

Kata kunci- Kecelakaan Kerja, Frekuensi Kecelakaan Kerja, Severity, Produktivitas
\end{abstract}

\section{Pendahuluan}

CV. Karya Nugraha tidak luput dari masalah yang dihadapi seperti tidak teraturnya tempat penyimpanan barang sebelum diolah yang sangat menghambat dalam proses produksi yang dapat mengakibatkan kecelakaan kerja. Kemudian jumlah ventilasi yang kurang, sehingga karyawan kurang nyaman dalam bekerja, merasa gerah, tidak konsentrasi, dan tidak bersemangat untuk melakukan aktivitasnya. Kebisingan berskala besar terutama mesin gerinda yang dapat menyebab kan pendengaran pekerja terganggu, hanya beberapa pekerja yang menggunakan pelindungan diri, dan juga tempat menyimpan barang yang berantakan. Berdasarkan data-data yang diperoleh dari CV. Karya Nugraha, terbukti bahwa masih terdapat kecelakaan kerja yang menimpa para pekerja ketika melakukan aktivitasaktivitas pekerjaannya, adapun data jumlah kecelakaan 2015 - 2017 dapat dilihat pada Tabel I. Hal tersebut dapat menimbulkan kerugian materi bagi perusahaan itu sendiri. Walaupun dengan peningkatan yang dilakukan perusahaan dalam mengutamakan keselamatan dan kesehatan kerja di CV. Karya Nugraha, kecelakaan kerja masih saja terjadi.

Keselamatan dan Kesehatan Kerja yang selanjutnya disingkat $\mathrm{K} 3$ adalah segala kegiatan untuk menjamin dan melindungi keselamatan dan kesehatan tenaga kerja melalui upaya pencegahan kecelakaan kerja dan penyakit akibat kerja [1]. K3 
merupakan upaya dalam menciptakan lingkungan kerja yang sehat dan selamat sehingga karyawan dapat melaksanakan tugas di area kerjanya dengan lancar [2]. Berdasarkan teori tersebut berarti K3 perlu diterapkan untuk mencegah terjadinya gangguan kesehatan dan kecelakaan yang diakibatkan pekerjaan, sehingga dapat mendukung terhadap tujuan perusahaan yaitu meningkatnya produktivitas kerja yang dapat meningkatkan keuntungan terhadap perusahaan.

TABEL I

POTENSI KONVERSI BEBERAPA RADIONUKLIDA

\begin{tabular}{|c|c|}
\hline Tahun & $\begin{array}{c}\text { Jumlah } \\
\text { Kecelakaan }\end{array}$ \\
\hline 2015 & 7 kasus \\
\hline 2016 & 8 kasus \\
\hline 2017 & 8 kasus \\
\hline
\end{tabular}

Sumber : Data CV. Karya Nugraha

Produktivitas pada dasarnya mencakup sikap mental yang selalu mempunyai pandangan bahwa mutu kehidupan ini harus lebih baik dari hari kemarin dan hari esok lebih baik dari hari ini [3]. Jadi, secara umum produktivitas diartikan sebagai perbandingan antara apa yang dihasilkan (output) dan masukan (input). Secara khusus produktivitas dapat diartikan kemampuan untuk menghasilkan sesuatu yang meliputi peningkatan efisiensi dan kecepatan menghasilkan suatu produk yang merupakan hasil gabungan efektivitas, efisiensi dan keekonomian. Keselamatan kerja merupakan usaha tindakan pengamanan proses produksi, menjamin agar tiap orang yang berada di tempat kerja senantiasa dalam kondisi aman. Keselamatan kerja dapat membantu peningkatan produksi [4]. Cara menanggulani kecelakaan kerja adalah dengan meniadakan unsur penyebab kecelakaan dan atau mengadakan pengawasan yang ketat.

Berdasarkan penelitian terdahulu, diketahui bahwa produktivitas karyawan di bagian maintenance dipengaruhi oleh factor keselamatan dan kesehatan kerja, yitu sebesr 73,6 \% dan 23,4\% dipengaruhi oleh faktor lain [5]. Hal senada juga didapat dalam penelitian di bagian produksi PT. Surya Asbes Cement Group Malang menyatakan bahwa Keselamatan dan Kesehatan Kerja berpengaruh signifikan terhadap kinerja karyawan [6].

Apakah tingkat kecelakaan kerja berpengaruh pada tingkat produktivitas karyawan di CV. Karya Nugraha?, hal ini perlu diteliti lebih lanjut.

\section{Metodologi Penelitian}

Penelitian yang dilakukan mengarah pada penelitian kuantitatif, adapun diagram alir penelitian dapat dilihat pada gambar 1 .

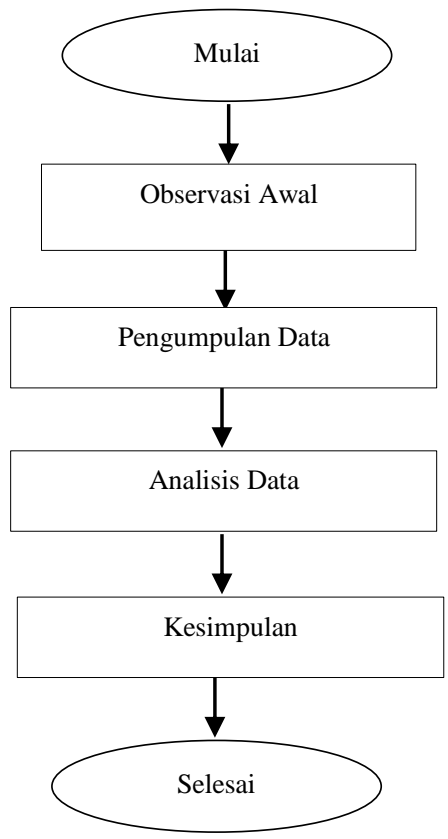

Gambar 1. Diagram alir penelitian

Pengumpulan data bisa dilakukan setelah dilakukan observasi awal dilakukan, sesudah itu dilakukan pengumpulan data, data tersebut yaitu data jam kerja, jumlah kecelakaan kerja, dan jumlah karyawan. Setelah pengumpulan data kemudian dilanjutkan dengan pengolahan data dimana data yang diperoleh peneliti dihitung untuk mendapatkan data seperti total jam hilang, jumlah jam kerja karyawan, frekuensi kecelakaan kerja, tingkat severity, nilai T selamat ( safe T score ), dan kemudian di analisis apa hubungannya dengan produktivitas dengan kesehatan dan keselamatan kerja. Setelah analisis dilakukan peneliti memberi kesimpulan dan saran untuk perusahaan supaya produktivitas meningkat dan tingkat kecelakaan kerja menurun.

Frekuensi/kekerapan cedera cacat yang menyatakan banyaknya kecelakaan yang terjadi tiap sejuta jam kerja manusia, dapat dinyatakan dengan rumus.

$$
\begin{aligned}
& \mathrm{F}=(\mathrm{n} \mathrm{X} 1.000 .000) / \mathrm{N} \\
& \text { dimana : }
\end{aligned}
$$$$
\mathrm{F}=\text { Tingkat frekuensi kekerapan cedera cacat }
$$$$
\mathrm{n}=\text { Jumlah kecelakaan yang terjadi }
$$$$
\mathrm{N}=\text { Jumlah jam kerja karyawan }
$$

Tingkat severity/keparahan kecelakaan kerja, menyatakan jumlah hari hilang akibat terjadinya 
kecelakaan kerja, untuk setiap satu juta jam kerja dari jumlah jam kerja karyawan. Jumlah jam kerja yang hilang meliputi jumlah hari yang diakibatkan cacat total sementara, dihitung berdasarkan tanggal (selama pekerja tidak mampu bekerja dan jumlah total cacat permanen dan kematian). Di dalam pengukuran pengaruh kecelakaan, juga harus dihitung angka beratnya kecelakaan untuk sejuta jam kerja dari jumlah jam kerja karyawan.

$$
\mathrm{S}=(\mathrm{H} \mathrm{X} \mathrm{1.000.000)}) / \mathrm{N}
$$

dimana :

$\mathrm{S}=$ Tingkat seferity/keparahan kecelakaan

$\mathrm{H}=$ Jumlah total jam hilang karyawan

$\mathrm{N}=$ Jumlah jam kerja karyawan

Pengukuran nilai $\mathrm{T}$ selamat bertujuan untuk membandingkan hasil tingkat frekuensi atau kekerapan cedera cacat suatu unit kerja pada masa lalu dan masa kini, sehingga dapat diketahui tingkat penurunan kecelakaan yang dicapai unit kerja tersebut. Nilai $\mathrm{T}$ selamat yang berdasarkan pada uji pengawasan mutu secara statistik. Metode yang di gunakan adalah pengujian " $t$ " atau Student Test. Safe - T-score.

$$
\begin{aligned}
& \text { Safe }-T-\text { Score }(\text { Sts })=(\text { F } 2-\text { F } 1) / \sqrt{ }((\text { F } 1) / N) \\
& \quad \text { Dimana : }
\end{aligned}
$$$$
\text { Sts = Nilai T Selamat (tak berdimensi) }
$$$$
\text { F1 = Tingkat Frekuensi kecelakaan kerja masa }
$$
lalu

F2 = Tingkat Frekuensi kecelakaan kerja masa kini

$\mathrm{N}=$ Jumlah jam kerja karyawan

Secara umum, hubungan produktivitas dengan kecelakaan kerja dapat dirumuskan sebagai berikut :

Produktivitas = (jumlah jam kerja karyawanjumlah jam hilang karyawan)/(Total jam kerja karyawan)

Semakin sedikit kecelakaan dan karyawan yang tidak masuk baik sakit maupun tanpa keterangan, maka semakin kecil pula hari kerja yang hilang dan mengakibatkan semakin tingginya tingkat produktivitas.

\section{HASIL PENELITIAN}

Pada hasil penelitian akan dibahas mengenai pengumpulan data dan pengolahan data .

\section{A. Pengumpulan Data}

Data hasil penelitian berupa jumlah kecelakaan (dapat dilihat pada Tabel II, jam kerja dan jumlah karyawan.

TABEL II

JUMLAH KECELAKAAN KERJA TAHUN 2015 - 2017

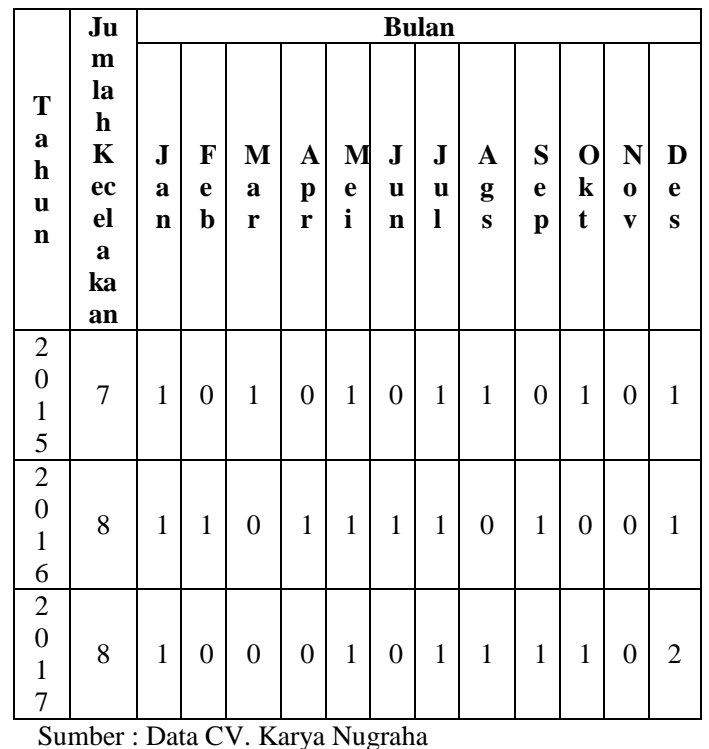

Jumlah jam kerja/bulan sama dengan 25 hari, dan jam kerja yang berlaku adalah 8 dengan istirahat 1 jam. Jam kerja mulai dari 08:00 - 16:00 WIB dan waktu istirahat tepat jam 12:00 WIB, hal ini berarti jumlah jam kerja per hari adalah 7 jam untuk setiap karyawan. Tabel III memperlihatkan jumlah karyawan dan total jam kerja.

TABEL III

JUMLAH KARYAWAN DAN JUMLAH JAM KERJA DI BAGIAN PRODUKSI TAHUN 2015 - 2017

\begin{tabular}{|c|c|c|c|}
\hline Tahun & $\begin{array}{c}\text { Jumlah } \\
\text { tenaga } \\
\text { kerja } \\
\text { (orang) }\end{array}$ & $\begin{array}{c}\text { Jumlah Jam } \\
\text { Kerja / } \\
\text { bulan ( jam ) }\end{array}$ & $\begin{array}{c}\text { Total jumlah } \\
\text { jam } \\
\text { kerja/Tahun } \\
\text { (jam })\end{array}$ \\
\hline 2015 & 14 & 2.450 & 29.400 \\
\hline 2016 & 15 & 2.625 & 31.500 \\
\hline 2017 & 17 & 2.975 & 35.700 \\
\hline
\end{tabular}

\section{B. Pengolahan Data}

Berdasarkan data yang diperoleh, maka dilakukan pengolahan data untuk menentukan :

(1) Tingkat frekuensi kecelakaan kerja.

(2) Tingkat severity atau keparahan kecelakaan kerja.

(3) Pengukuran Nilai T-Selamat (Nts)

(4) Produktivitas

Berdasarkan perhitungan tingkat frekuensi kecelakaan kerja, hasilnya dapat dilihat pada Tabel IV, Tingkat severity atau keparahan kecelakaan 
kerja dapat dilihat pada Tabel V, Data Nilai Tselamat dapat dilihat pada Tabel VI dan Data produktivitas dapat dilihat pada Tabel VII

TABEL IV

TingKat FreKuensi KecelaKaAn KeRJa di Bagian Produks TAHUN 2015 - 2017

\begin{tabular}{|c|c|c|}
\hline Tahun & Jumlah Kecelakaan Kerja & F \\
\hline 2015 & 7 & 238,09 \\
\hline 2016 & 8 & 253,96 \\
\hline 2017 & 8 & 224,08 \\
\hline
\end{tabular}

Contoh perhitungan :

$$
\begin{aligned}
\mathrm{F}(2015) & =(7 \times 1.000 .000) / 29.400 \\
& =238,09 \text { per } 1.000 .000 \text { jam keria }
\end{aligned}
$$

Keterangan : Satu juta jam adalah jumlah jam kerja dari 14 karyawan yang bekerja 2.450 jam per bulan dan 29.400 jam per tahun (2015).

TABEL V

TingKat SEVERITY KeCELAKAAN KERJA Di BAGIAN PRODUKSI TAHUN $2015-2017$

\begin{tabular}{|c|c|c|c|}
\hline Tahun & $\begin{array}{c}\text { Jumlah jam } \\
\text { hilang }\end{array}$ & $\begin{array}{c}\text { Jumlah jam } \\
\text { kerja }\end{array}$ & S \\
\hline 2015 & 287 & 29.400 & $9.761,9$ \\
\hline 2016 & 294 & 31.500 & $9.333,3$ \\
\hline 2017 & 280 & 35.700 & $7.843,1$ \\
\hline
\end{tabular}

Contoh perhitungan tingkat severity adalah sebagai berikut :

$$
\begin{aligned}
\mathrm{S}(2015)= & (287 \mathrm{X} 1.000 .000) / 29.400 \\
= & 9.762 \mathrm{jam} \text { per } 1.000 .000 \mathrm{jam} \\
& \text { kerja }
\end{aligned}
$$

Ini berarti bahwa dalam setahun kira-kira 9.762 jam yang hilang untuk setiap 1.000.000 jam kerja yang dijalankan atau 9.762 jam per juta jam kerja yang dijalankan.
TABEL VI

DATA NILAI T-SELAMAT

DI BAGIAN PRODUKSI TAHUN 2015 - 2017

\begin{tabular}{|c|c|c|c|c|}
\hline Tahun & $\begin{array}{c}\text { Jumlah } \\
\text { jam } \\
\text { kerja }\end{array}$ & F1 & F2 & STs \\
\hline 2015 & 29.400 & - & 238,09 & \\
\hline 2016 & 31.500 & 238,09 & 253,96 & 182,54 \\
\hline 2017 & 35.700 & 253,96 & 224,08 & $-354,27$ \\
\hline
\end{tabular}

Contoh perhitungan nilai T-selamat (Sts) :

$$
\begin{aligned}
\operatorname{STs}(2016)= & (253,96-238,09): \\
& \sqrt{ }(238,09 / 31.500) \\
= & 182,54
\end{aligned}
$$

Safe T Score (STs) adalah angka yang tidak mempunyai dimensi. Arti STs positif menunjukkan keadaan yang memburuk sedangkan angka negatif menunjukkan keadaan membaik.

TABEL VII

TingKat PRodukTIVITAS DI BAgIAN PRODUKSI TAHUN 2015 - 2017

\begin{tabular}{|c|c|c|c|}
\hline Tahun & $\begin{array}{c}\text { Jumlah } \\
\text { total Jam } \\
\text { Hilang }\end{array}$ & $\begin{array}{c}\text { Jumlah } \\
\text { Jam } \\
\text { Kerja }\end{array}$ & Produktivitas \\
\hline 2015 & 287 & 29.400 & 0,9902 \\
\hline 2016 & 294 & 31.500 & 0,9906 \\
\hline 2017 & 280 & 35.700 & 0,9921 \\
\hline
\end{tabular}

Contoh perhitungan tingkat produktivitas adalah sebagai berikut :

$$
\begin{aligned}
\text { Produktivitas }(2015)= & \frac{29.400-287}{29.400} \\
& =0,9902
\end{aligned}
$$

\section{PEMBAHASAN}

A. Analisis Tingkat Frekuensi Kecelakaan Kerja

Berdasarkan Tabel IV dan Gambar 2. dapat diketahui bahwa tingkat Frekuensi kecelakaan kerja yang terjadi dari tahun 2015 - 2016 mengalami kenaikan, hal ini disebabkan karena jumlah kecelakaan kerja di tahun 2016 lebih banyak dibanding tahun 2015, nilainya tidak sebanding dengan jumlah jam kerja dikarenakan ada penambahan 1 orang karyawan. Sedangkan pada tahun 2017 mengalami penurunan tingkat frekuensi kecelakaan, walaupun jumlah 
kecelakaan sama dengan tahun 2016, namun dalam hal ini jumlah jam kerja lebih besar karena adanya penambahan 2 orang karyawan dari tahun 2016.

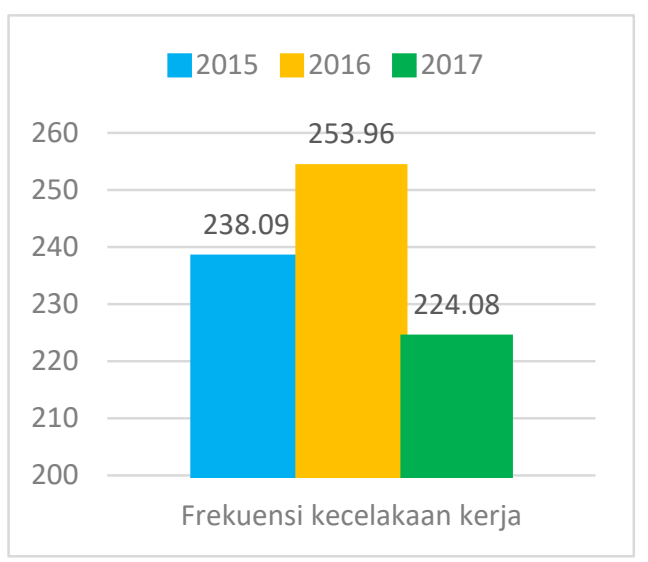

Gambar 2. Grafik tingkat frekuensi di bagian produksi CV. Karya Nugraha

\section{B. Analisis Tingkat Severity/Keparahan Kecelakaan Kerja}

Berdasarkan Tabel V dan gambar 3, dapat diketahui bahwa tingkat severity yang paling tinggi yaitu pada tahun 2015 hal ini disebabkan oleh rasio antara jam kerja hilang dan jumlah jam kerja yang lebih tinggi bila dibandingkan tahun 2016 dan 2017. Sedangkan pada tahun 2017 tingkat severity lebih kecil walaupun jumlah kecelakaannya sama dengan 2016, namun jumlah jam kerja hilang di tahun 2017 lebih kecil dibandingkan tahun 2016, serta didukung juga dengan jumlah jam kerja yang lebih besar sehingga menjadikan rasio antara jam kerja hilang dan jumlah jam kerja menjadi lebih kecil.

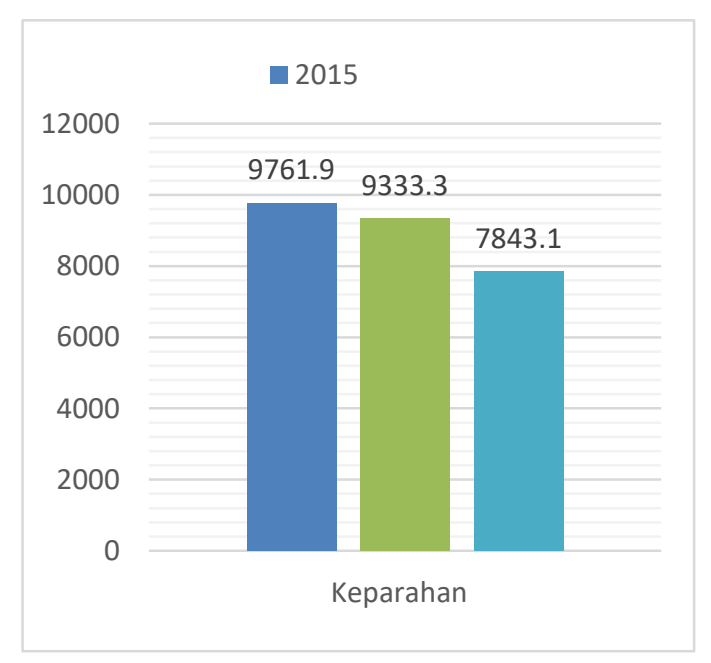

Gambar 3. Grafik tingkat keparahan di bagian produksi CV. Karya Nugraha

\section{Analisis Nilai T-selamat (STs)}

Berdasarkan Tabel VI dan gambar 4, dapat diketahui bahwa STs di 2016 bernilai positif mengindikasi bahwa keadaan memburuk dari tahun 2015, hal ini disebabkan karena tingkat frekuensi kecelakaan tahun 2016 lebih besar dibanding 2015. Sedangkan pada tahun 2017 STs bernilai negatif, mengindikasi bahwa keadaan menjadi lebih baik, diakibatkan tingkat keparahan dan frekuensi dari kecelakaan pada tahun ini lebih kecil dibanding tahun sebelumnya.

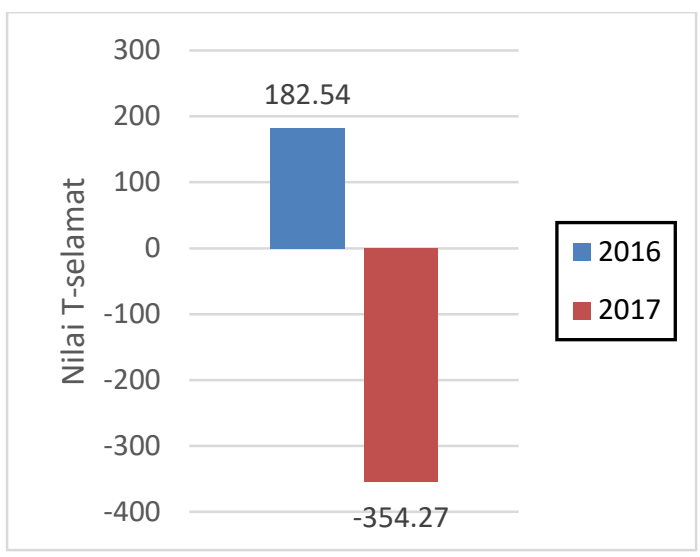

Gambar 4. Grafik Nilai T-selamat di bagian produksi CV Karya Nugraha

\section{Analisis Nilai T-selamat (STs)}

Berdasarkan Tabel VII dan gambar 5, maka diketahui bahwa tingkat produktivitas meningkat setiap tahunnya. Ini di pengaruhi oleh tingkat jumlah jam kerja yang meningkat setiap tahunnya dikarenakan jumlah pekerja yang bertambah, walau tingkat frekuensi tahun 2015-2016 meningkat, tetapi disebabkan ada peningkatan jumlah jam kerja maka hal itu berpengaruh pada tingkat produktivitas yang tidak mengalami penurunan.

Hal ini berlaku juga pada jumlah kecelakaan kerja terhadap produktivitas tahun 2016 - 2017 , hasil pengukuran tingkat frekuensi kecelakaan kerja diketahui pada tahun 2016-2017 kecelakaan tidak mengalami penaikan maupun penurunan tetapi produktivitas mengalami peningkatan, dan hal ini juga di pengaruhi oleh tingkat jumlah jam kerja yang meningkat setiap tahunnya dikarenakan jumlah pekerja yang bertambah serta dilihat dari jam kerja hilang pada tahun 2017 lebih kecil dibandingkan tahun 2016, sehingga menandakan tingkat keparahan kecelakaan yang relatif lebih rendah. 


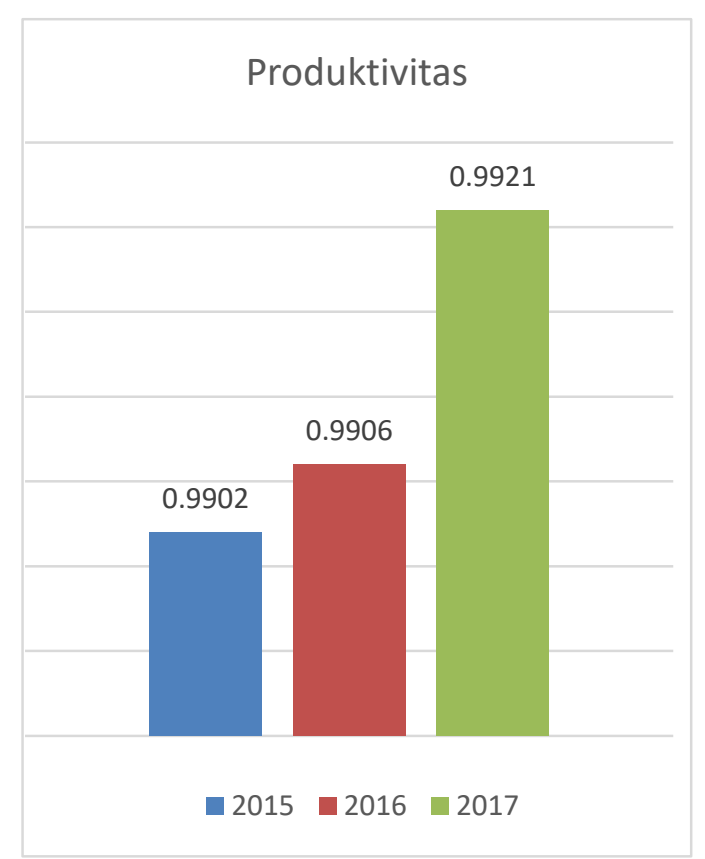

Gambar 5. Grafik Nilai T-selamat di bagian produksi CV Karya Nugraha

\section{KESIMPULAN}

Berdasarkan evaluasi, pengukuran dan analisis yang telah dilakukan di CV. Karya Nugraha dapat ditarik kesimpulan sebagai berikut:

1) Tingkat frekuensi kecelakaan kerja berpengaruh terhadap produktivitas

2) Tingkat severity/keparahan kecelakaan kerja berpengaruh terhadap produktivitas kerja.

3) Jumlah jam kerja (meningkatnya jumlah karyawan) dapat meningkatkan produktivitas kerja.

\section{REFERENSI}

[1] Republik Indonesia, "Peraturan Pemerintah Republik Indonesia Nomor 50 Tahun 2012 Tentang Penerapan Sistem Manajemen Keselamatan dan Kesehatan Kerja" Jakarta, 2012.

[2] S. Prawirosentono, Manajemen Sumber Daya Manusia: Kebijakan Kinerja Karyawan, 1st ed. Yoyakarta: BPFE, 2010.

[3] J. Ravianto, Produktivitas dan Tenaga Kerja, Seri Produktivitas VII. Jakarta: SIUP, 1986.

[4] S. P. Kusumah, Keselamatan Kerja dan Pencegahan Kecelakaan. Jakarta: CV. Haji Mas Agung, 1987.

[5] M. Nur and C. D. Oktafia, "Pengaruh Pelaksanaan Program Keselamatan dan Kesehatan Kerja Terhadap Produktivitas Kerja Karyawan," J. Tek. Ind. J. Has. Penelit. dan Karya Ilm. Tek. Ind., vol. 3, no. 2, pp. 116-125, 2017.

[6] R. Kartikasari and B. Swasto, "Pengaruh Keselamatan dan Kesehatan Kerja Karyawan Terhadap Kinerja Karyawan (Studi Pada Karyawan Bagian Produksi PT. Surya Asbes Cement Group Malang)" J. Adm. Bisnis S1 Univ. Brawijaya, 2017. 